\title{
Wnt5a / planar cell polarity signaling pathway in urothelial carcinoma, a potential prognostic biomarker
}

\author{
Mark Saling ${ }^{1}$, Jordan K. Duckett ${ }^{1}$, Ian Ackers ${ }^{1}$, Karen Coschigano ${ }^{1,2,3}$, Scott \\ Jenkinson ${ }^{4}$ and Ramiro Malgor ${ }^{1,2,3}$ \\ ${ }^{1}$ Department of Biomedical Sciences, Heritage College of Osteopathic Medicine, Ohio University, Athens, Ohio, USA \\ ${ }^{2}$ Interdisciplinary Program in Molecular and Cellular Biology, Ohio University, Athens, Ohio, USA \\ ${ }^{3}$ The Diabetes Institute of Ohio University, Athens, Ohio, USA \\ ${ }^{4}$ University Medical Associates, Inc., Pathology, Athens, Ohio, USA \\ Correspondence to: Ramiro Malgor, email: malgor@ohio.edu \\ Keywords: urothelial carcinoma, bladder, Wnt5a, epithelial mesenchymal transition, biomarker \\ Received: August 25, $2016 \quad$ Accepted: February 01, $2017 \quad$ Published: March 03, 2017 \\ Copyright: Saling et al. This is an open-access article distributed under the terms of the Creative Commons Attribution License (CC-BY), \\ which permits unrestricted use, distribution, and reproduction in any medium, provided the original author and source are credited.
}

\section{ABSTRACT}

Bladder cancer is the fourth most common cancer in men and the most common malignancy of the urinary tract. Bladder cancers detected at an early stage have a very high five-year survival rate, but when detected after local metastasis the rate is only about $\mathbf{5 0 \%}$. Our group recently reported a positive correlation between the expression of Wnt5a, a member of the Wnt proteins family, and histopathological grade and stage of urothelial carcinoma (UC). The objective of this study was to analyze UC cases reported in Athens, Ohio and investigate the major components of Wnt5a / planar cell polarity (PCP) signaling pathway in UC human tissue samples and UC cell lines.

Formalin fixed and paraffin embedded transurethral resection tissues were immunostained for Wnt5a, Ror-2, CTHRC1 and E-cadherin. In addition, in vitro studies using UC cell lines were investigated for Wnt5a/PCP signaling and epithelial mesenchymal transition (EMT) gene expression. The IHC results showed a correlation between the expression of Wnt5a, Ror2 and CTHRC1 with high histological grade of the tumor, while E-cadherin showed an opposite trend of expression. Real time RT-PCR results showed that RNA expression of the Wnt5a/ PCP pathway genes vary in low and high grade UC cell lines and that the high grade cell lines exhibited signs of EMT.

These findings support that Wnt5a-Ror2 signaling plays a role in UC, support the potential use of Wnt5a as a prognostic marker and provide evidence that Wnt5a signaling may be used as an effective molecular target for novel therapeutic tools.

\section{INTRODUCTION}

Bladder cancer is the fourth most common cancer among men. About 74,000 new cases are diagnosed, and result in 16,000 deaths each year in the United States [1]. Many bladder cancers at first diagnosis are found still confined to the superficial layer of the bladder wall, but $35 \%$ of the diagnoses have invaded into deeper layers including muscle. Approximately $95 \%$ of bladder cancers arise from the urothelium, causing urothelial carcinoma (UC) $[2,3]$.

The pathological grade is essential criteria for determining prognosis and patient therapeutic management
$[3,4]$. Urothelial carcinoma is diagnosed and treated via transurethral resection (TUR). The World Health Organization (WHO) devised a 2 tier system in 2004, distinguishing low grade and high grade UC tumors. Low grade tumors maintain recognizable architecture with minimal changes in polarity, nuclear size, shape, and chromatin texture, while high grade tumors have disorganized architecture and frequent mitotic figures as well as increased pleomorphism and clumped chromatin [2]. The heterogeneous UC group includes tumors with different biological behaviors, and recurrence after the initial treatment is a common feature [3].

Multiple biomarkers are currently being investigated in the use for diagnosis and prognosis of bladder cancer, 
including Wnt5a [5-7]. Wnt5a belongs to the Wnt family of proteins, which is a group of evolutionarily conserved glycoproteins shown to play a key role in embryonic development, regulating cell proliferation, fate, and motility $[8,9]$. A peculiarity of the Wnt protein family is the large number of ligands and receptors involved, leading to the activation of multiple downstream pathways [8]. The pathways can be classified into two categories, canonical or transforming Wnts and non-canonical or non-transforming Wnts. Aberrant activation of Wnt signaling pathways have been involved in a large variety of diseases [10, 11]. Activation or inhibition of Wnt5a signaling, a member of the noncanonical Wnt signaling pathways has been described as an important event in pathogenesis of cancer as tumor suppressor or tumor promoter, in a variety of malignancies $[12,13]$. Moreover, it has been shown that Wnt5a can work through canonical $/ \beta$-catenin dependent or noncanonical $/ \beta$ catenin independent signaling pathways [10, 14].

Wnt5a, can activate numerous pathways based on the use of a large variety of receptors and co-receptors, including the Frizzled receptor (Fzd) family, tyrosine kinase-like orphan receptor 2 (Ror2), and collagen triple helix repeatcontaining protein 1 (CTHRC1) $[15,16]$, among others. Ror2, a member of the Ror family of receptor tyrosine kinases, is involved in Wnt/planar cell polarity (PCP) and has been shown to play a role in the epithelial-mesenchymal transition $[17,18]$. CTHRC1 selectively activates the Wnt/ PCP pathway through activation of RhoA and Rac, and it enhances the formation of the Wnt-Fzd-Ror2 complex [16]. It is thought that CTHRC1 stabilizes the Wnt ligand/Frizzled receptor complex during Wnt/PCP pathway activation [16]. CTHRC1 has been reported to be highly expressed in pancreatic cancer and hepatocellular carcinoma [19], but neither the role of Ror2 or CTHRC1 has been studied in UC.

Previously, we reported a positive correlation between Wnt5a expression and histopathological grade of UC in human samples [6]. This finding led us to speculate that Wnt5a could play a role in UC pathogenesis and could be a potential biomarker to explore for this type of cancer. The aim of this current study was to investigate Wnt5a/ Ror2/PCP signaling as a potential pathway functioning in the pathogenesis of aggressive UC cases. In this study we found that Ror2 expression shows a similar pattern as Wnt5a in the tissue samples. More important was the finding that the correlation between Ror2 and pathological grade is even stronger than the correlation between Wnt5a and pathological grade. Additionally, we found that CTHRC1 is highly expressed in the tumors with high Ror2 expression. In vitro studies using three UC cell lines, RT4, J82 and T24, the first isolated from a low grade UC and the last two from high grade UC tumors, showed a similar trend of RNA expression for Wnt5a and Ror2. We conclude that the Wnt5a/PCP pathway may be playing an important role in aggressive cases of $\mathrm{UC}$, providing potential applications for development of new diagnostic and treatment strategies for UC.

\section{RESULTS}

\section{Epidemiologic study}

For the period 2004-2014, 77 cases were diagnosed as UC through the UMA Pathology lab and reviewed in this study. A total of 75 cases where confirmed as UC with $52(69.3 \%)$, being high grade (HG) lesions and 23 $(30.7 \%)$, being low grade (LG) lesions. Two other cases $(2.6 \%)$ were diagnosed as papillary urothelial neoplasm of low malignant potential (PUNLMP). The average patient age for all cases was 71.9 years. Figure 1A shows the male-dominant, 61 of $77(79.2 \%)$, gender distribution of the 77 cases collected. In the group studied with the diagnosis of UC the likelihood for men and women to have HG versus LG tumors were 2.5 and 1.5 times, respectively (Figure 1B).

\section{Histopathological analysis of human UC samples}

Histological grade was determined for 15 samples of human UC included in the study. Based on the pathological reports 7 samples were low grade and 8 were high grade urothelial carcinomas. Of the 15 samples, 5 (4 high grade, 1 low grade) showed muscular invasion and thus were at least stage T2. The other 10 cases only invaded the lamina propria. Based on microscopic appearance 3 of the invasive tumors showed a solid pattern, while the rest $(n=12)$ showed papillary aspect.

\section{Wnt5a and Ror2 protein expression correlated with increasing histological grade}

Immunohistochemical analysis revealed a statistically significant correlation between Wnt5a protein expression and tumor grade (Sig. 0.032) (Figure 2A and 2B). This result supported our previous study [6]. In addition, we found a higher correlation between Ror2 expression in the tumor and tumor grade and between Ror2 and Wnt5a protein expression in tumor tissue, (Sig. 0.009 and 0.002 ), respectively (Figure 2B). Correlation between Wnt5a and CTHRC1 was significant (0.029). Correlation between Ror2 and CTHRC1 expression was also highly significant (0.008). The expression of Wnt5a, ROR2, and CTHRC1 increased with the histological grade while E-cadherin showed an opposite trend (Figure 2A).

\section{Varying combinations of expression of Wnt5a, Ror2 and CTHRC1 in three UC cell lines}

Real-time RT-PCR analyses of RNA isolated from RT4, J82 and T24 cells revealed dramatically different levels of expression of Wnt5a between the three cell types (Figure 3A). In comparison to expression in the low grade RT4 cell line, Wnt5a RNA expression was dramatically increased in the high grade J82 cell line and severely 
decreased in the high grade T24 cell line. Interestingly, Ror2 expression paralleled Wnt5a expression in the high grade J82 and T24 cell lines, but was also high in the low grade RT4 cell line (Figure 3B). CTHRC1 expression was high in both high grade cell lines, J82 ant T24, in comparison to the low grade RT4 cell line (Figure 3B). Immunofluorescence analysis of protein expression within the cell lines roughly paralleled RNA expression for Wnt5a and CTHRC1. In contrast, Ror2 protein expression appeared to be low in the high grade J82 cell line, in contrast to the high RNA expression. The confocal images show co-expression and co-localization of Ror2 and CTHRC1 in RT4 and J82, being less evident for T24 cell line (Figure 4).

\section{RNA expression of CDH1 and vimentin suggest an epithelial-mesenchymal transition for the high grade $\mathrm{UC}$ cell lines}

As expected for an epithelial cell, RNA expression of $\mathrm{CDH} 1$ was easily detected, but vimentin levels were extremely low in the low grade RT4 cell line (Figure 3C). In contrast, RNA expression of vimentin was greatly increased in the high grade J82 cell line and detectable, but not significantly increased in the high grade T24 cell line in comparison to the low grade RT4 cell line; CDH1 expression was extremely low in both high grade cell lines (Figure 3C).

A

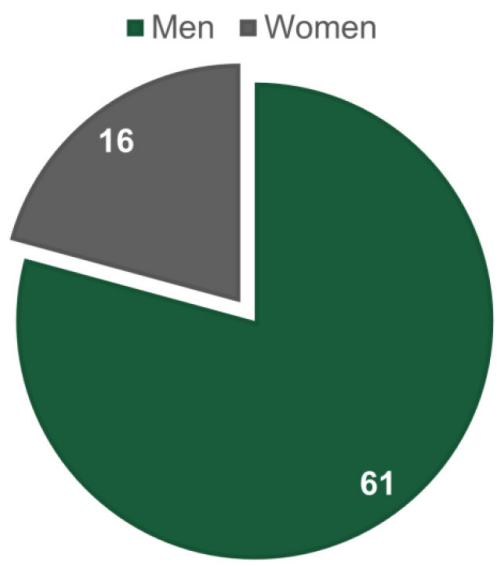

B Grade of Lesions per Men and Women

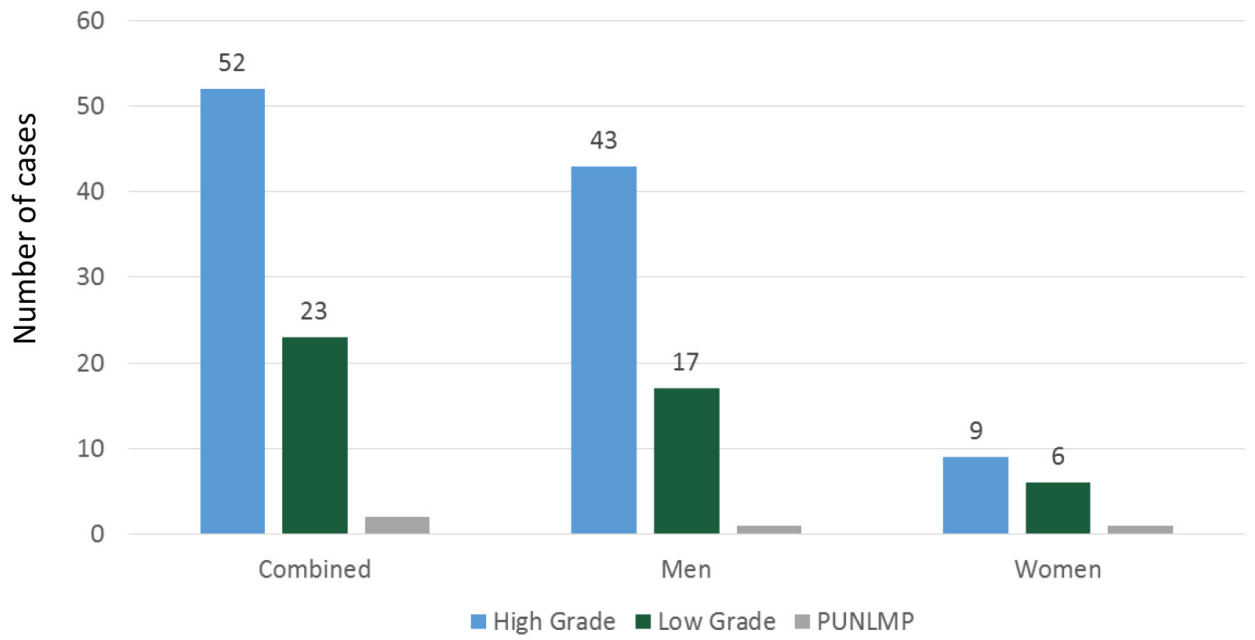

Figure 1: (A) Gender distribution. Of the 77 cases collected 61 (79.2\%), were men and 16 (20.8\%), were women. (B) Grade analysis: Comparison of high grade to low grade tumors for male and females. In this population, the likelihood to have high grade or low grade tumors were 2.5 and 1.5 for men and women respectively. 
A

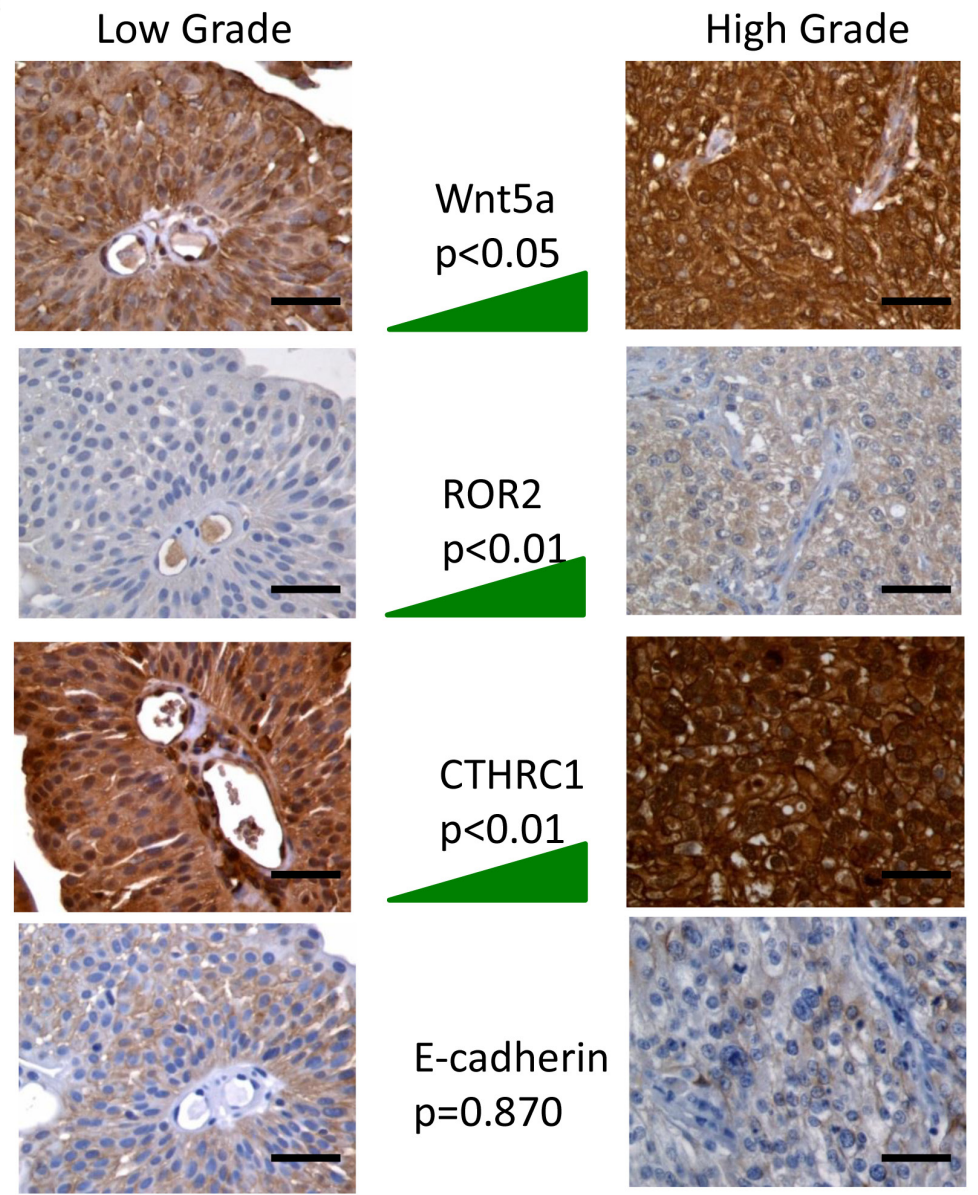

\section{B}

\begin{tabular}{|c|c|c|c|c|}
\hline & Tumor grade & Wnt5a & Ror2 & CTHRC1 \\
\hline \multicolumn{5}{|l|}{ Tumor grade } \\
\hline Pearson correlation & 1 & .618 & .690 & .911 \\
\hline Sig. (2-tailed) & & .032 & .009 & .001 \\
\hline $\mathbf{N}$ & 13 & 12 & 13 & 11 \\
\hline \multicolumn{5}{|l|}{ Wnt5a } \\
\hline Pearson correlation & & 1 & .794 & .655 \\
\hline Sig. (2-tailed) & & & .002 & .029 \\
\hline $\mathbf{N}$ & & 12 & 12 & 11 \\
\hline \multicolumn{5}{|l|}{ ROR2 } \\
\hline Pearson correlation & & & 1 & .747 \\
\hline Sig. (2-tailed) & & & & .008 \\
\hline $\mathbf{N}$ & & & 13 & 11 \\
\hline \multicolumn{5}{|l|}{ CTHRC1 } \\
\hline Pearson correlation & & & & 1 \\
\hline Sig. (2-tailed) & & & & \\
\hline & & & & 11 \\
\hline
\end{tabular}

Figure 2: (A) Immunohistochemical analysis of human specimens of urothelial carcinoma of the bladder for the expression of Wnt5a, ROR2, CTHRC1 and E-cadherin. Left column, tissue sections from a representative case of low grade urothelial carcinoma; the right column, tissue sections from a representative case of high grade urothelial carcinoma. The middle column represents the trend of expression for each protein in all 15 samples. The expression of Wnt5a, ROR2, and CTHRC1 increases in high grade tumors while E-cadherin shows an opposite trend. Bar=50 $\mu \mathrm{m}$. (B) Statistical analysis was performed to investigate the correlation between tumor histological grade and immunostaining for Wnt5a, Ror2, CTHRC1, and E-cadherin. Statistical significance was tested at an alpha of 0.05. The software PASW Statistics 18 was used for data analysis (Pearson Education, New York City, NY). 


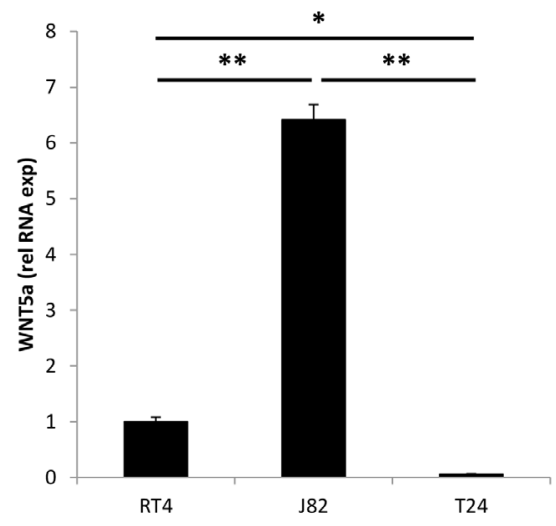

B

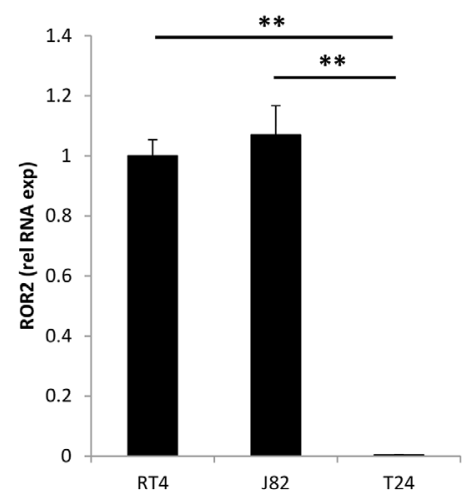

C

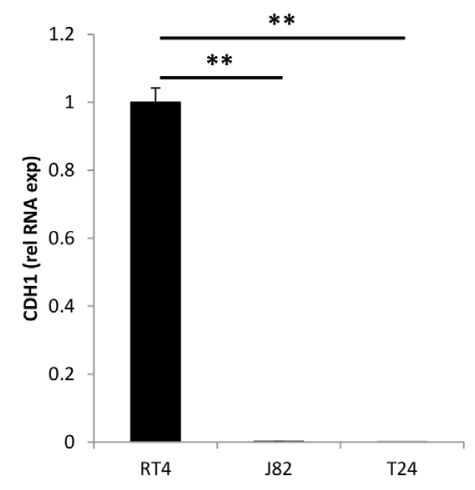

$*: P<0.01$

**: $P<0.001$

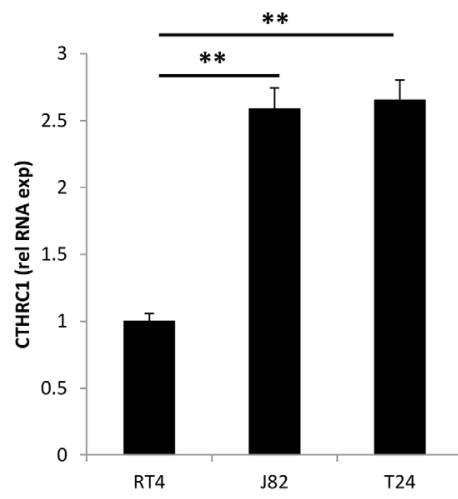

$*: P<0.01$

**: $\mathrm{P}<0.001$

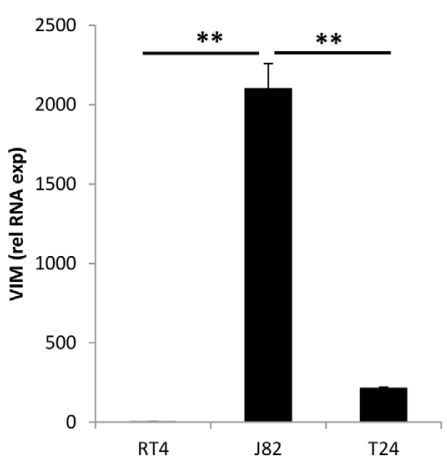

Figure 3: Real Time RT-PCR, analysis of RNA expression. Wnt5a (A), Ror2 and CTHRC1 (B), E-cadherin and vimentin (C), in RT4, J82 and T24 urothelial carcinoma cell lines. 


\section{DISCUSSION}

The Ohio Cancer Incidence Surveillance System (OCISS) reported 4,669 new cases of bladder cancer for the period 1999-2007 and 2,806 new cases for the period 2006-2010 [20]. At the national level, according to the American Cancer Society, there was an expected 74,690 new cases of bladder cancer for the United States and for Ohio an estimated 3,110 new cases for 2014. In our analysis of $77 \mathrm{UC}$ cases reviewed for a 10 year period (2004-2014) in Southeast Ohio, the male to female ratio was 3.8:1, and the mean age was 72 years, in agreement with previous studies [4]. Although UC is not a cancer with high mortality rate such as breast, colon or lung cancer, it has many biological and clinical features that make it interesting to study. First, bladder cancer detected at an early stage has a five year survival rate of around $92 \%$, but when detected after local metastasis the rate is only about $50 \%$ [21]. For this reason, early detection is an important area of investigation. Second, UC has a high percentage of intravesical recurrence (30-80\%) after TUR treatment, even for non-muscle-invasive UC cases [21].
RT4
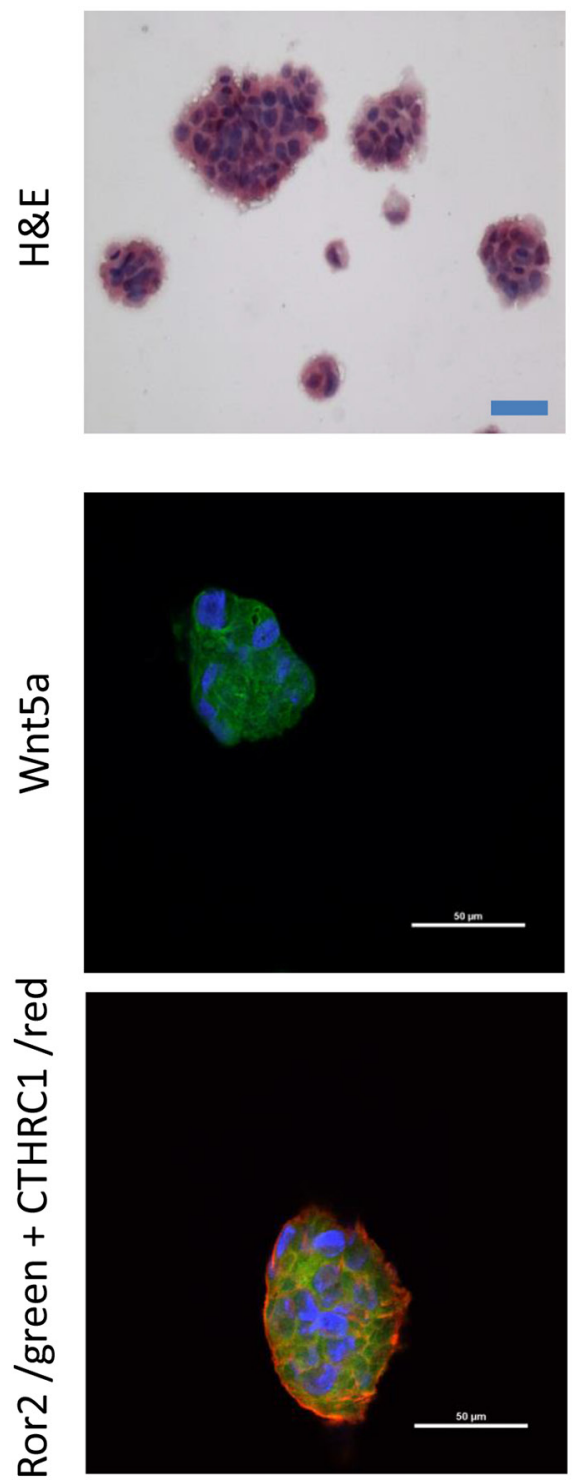

J82
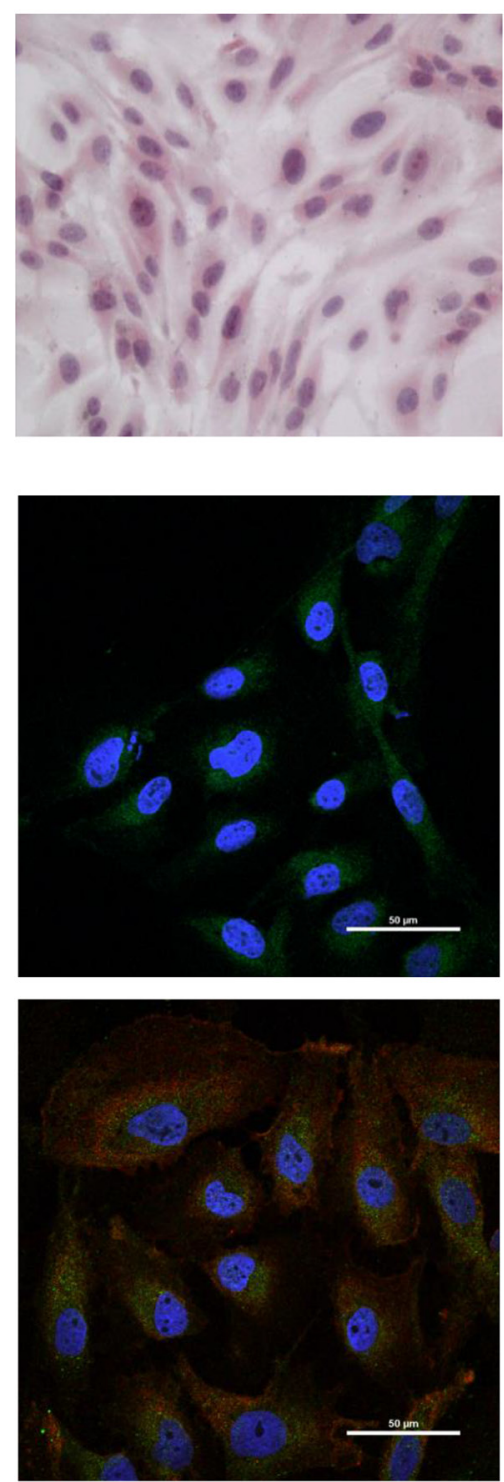

T24
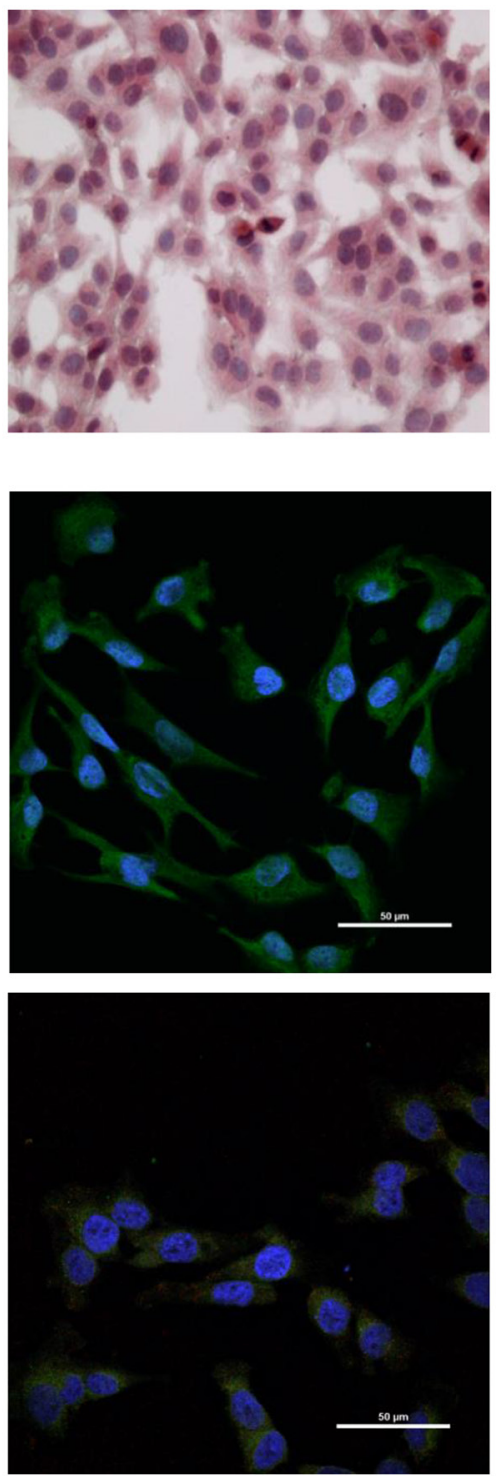

Figure 4: Immunofluorescence of RT4, J82 and T24 cell lines for the expression of Wnt5a, ROR2, and CTHRC1. Top row: H\&E stain shows morphological differences between each cell line. Middle row: confocal microscopy images show the expression of Wnt5a (green) for each cell line. Bottom row: confocal microscopy image of the merge expression of Ror2 (green) and CTHRC1 (red) for each cell line. Although the co-expression and colocalization of Ror2 and CTHRC1 is present in all cell lines, it is clearest for RT4 and J82 cell lines. 
Table 1: Characterization of human urothelial carcinoma cell lines

\begin{tabular}{|c|c|c|c|c|c|c|c|c|c|}
\hline $\begin{array}{l}\text { Cell } \\
\text { line }\end{array}$ & $\begin{array}{c}\text { Origin } \\
\text { of tumor } \\
\text { cells* }\end{array}$ & $\begin{array}{c}\text { Clinical } \\
\text { stage of } \\
\text { disease }\end{array}$ & $\begin{array}{c}\text { Histological } \\
\text { grade* }\end{array}$ & Tumorigenic* & $\begin{array}{c}\text { Wnt5a } \\
\text { RNA } \\
\text { expression } \\
\#\end{array}$ & $\begin{array}{c}\text { Ror2 } \\
\text { RNA } \\
\text { expression } \\
\#\end{array}$ & $\begin{array}{c}\text { CTHRC1 } \\
\text { RNA } \\
\text { expression } \\
\#\end{array}$ & $\begin{array}{c}\text { E-cadherin } \\
\text { RNA } \\
\text { expression } \\
\#\end{array}$ & $\begin{array}{c}\text { Vimentin } \\
\text { RNA } \\
\text { expression } \\
\#\end{array}$ \\
\hline RT4 & $\begin{array}{l}\text { recurrent } \\
\text { in bladder }\end{array}$ & $\mathrm{T} 2$ & $\begin{array}{c}\text { Low grade } \\
\text { (G1) }\end{array}$ & Yes & + & + & + & + & + \\
\hline J82 & $\begin{array}{l}\text { bladder } \\
\text { primary }\end{array}$ & $\mathrm{T} 3$ & $\begin{array}{l}\text { High grade } \\
\text { (G3) }\end{array}$ & Yes & $\begin{array}{l}\text { highly } \\
\text { increased }\end{array}$ & increased & increased & decreased & $\begin{array}{l}\text { highly } \\
\text { increased }\end{array}$ \\
\hline $\mathrm{T} 24$ & $\begin{array}{l}\text { recurrent } \\
\text { in bladder }\end{array}$ & NR & $\begin{array}{l}\text { High grade } \\
\text { (G3) }\end{array}$ & No & decreased & $\begin{array}{c}\text { highly } \\
\text { decreased }\end{array}$ & increased & decreased & increased \\
\hline
\end{tabular}

*Cancer Res 46, 3630-36, July 1986 [19]

\# relative to RT4

Table 2: Primer sequences used for real-time RT-PCR analyses

\begin{tabular}{|c|c|c|c|}
\hline Gene & $\begin{array}{l}\text { GenBank accession } \\
\text { number }\end{array}$ & Primer sequences (5'- 3') & Primer design* \\
\hline $\begin{array}{l}\text { Glyceraldehyde-3-phosphate } \\
\text { dehydrogenase (GAPDH) }\end{array}$ & NM_001256799 & $\begin{array}{l}\text { (+) CTGGGCTACACTGAGCACC } \\
\text { (-) AAGTGGTCGTTGAGGGCAATG }\end{array}$ & $\begin{array}{l}\text { PrimerBank } \\
\text { ID } 378404907 \mathrm{c} 3\end{array}$ \\
\hline Beta-2-microglobulin (B2M) & NM_004048 & $\begin{array}{l}\text { (+) GAGGCTATCCAGCGTACTCCA } \\
\text { (-) CGGCAGGCATACTCATCTTTT }\end{array}$ & $\begin{array}{l}\text { PrimerBank } \\
\text { ID } 37704380 \mathrm{c} 1\end{array}$ \\
\hline $\begin{array}{l}\text { Hypoxanthine } \\
\text { phosphoribosyltransferase } 1 \\
\text { (HPRT1) }\end{array}$ & NM_000194 & $\begin{array}{l}\text { (+) CCTGGCGTCGTGATTAGTGAT } \\
\text { (-) AGACGTTCAGTCCTGTCCATAA }\end{array}$ & $\begin{array}{l}\text { PrimerBank } \\
\text { ID } 164518913 \mathrm{c} 1\end{array}$ \\
\hline $\begin{array}{l}\text { Succinate dehydrogenase complex, } \\
\text { subunit A, flavoprotein (SDHA) }\end{array}$ & NM_004168 & $\begin{array}{l}\text { (+) CAAACAGGAACCCGAGGTTTT } \\
\text { (-) CAGCTTGGTAACACATGCTGTAT }\end{array}$ & $\begin{array}{l}\text { PrimerBank } \\
\text { ID } 156416002 \mathrm{c} 1\end{array}$ \\
\hline Ubiquitin C (UBC) & NM_021009 & $\begin{array}{l}\text { (+) CTGGAAGATGGTCGTACCCTG } \\
\text { (-) GGTCTTGCCAGTGAGTGTCT }\end{array}$ & $\begin{array}{l}\text { PrimerBank } \\
\text { ID } 305632811 \mathrm{c} 1\end{array}$ \\
\hline $\begin{array}{l}\text { Wingless-type MMTV integration } \\
\text { site family, member } 5 \mathrm{~A} \text { (WNT5A) }\end{array}$ & NM_003392 & $\begin{array}{l}\text { (+) TCGACTATGGCTACCGCTTTG } \\
\text { (-) CACTCTCGTAGGAGCCCTTG }\end{array}$ & $\begin{array}{l}\text { PrimerBank } \\
\text { ID } 371506361 \mathrm{c} 3\end{array}$ \\
\hline $\begin{array}{l}\text { Receptor tyrosine kinase-like } \\
\text { orphan receptor } 2 \text { (ROR2) }\end{array}$ & NM_004560 & $\begin{array}{l}\text { (+) TCCGAACGACCCTTTAGGAC } \\
\text { (-) TTTAGCCACCGCACGTTAGG }\end{array}$ & $\begin{array}{l}\text { PrimerBank } \\
\text { ID } 317008621 \mathrm{cl}\end{array}$ \\
\hline $\begin{array}{l}\text { Collagen triple helix repeat } \\
\text { containing } 1 \text { (CTHRC1) }\end{array}$ & NM_001256099 & $\begin{array}{l}\text { (+) TGTTCAGTGGCTCACTTCGG } \\
\text { (-) TCCAGCACCAATTCCTTCACA }\end{array}$ & PrimerBLAST \\
\hline $\begin{array}{l}\text { Cadherin 1, type } 1, \text { E-cadherin } \\
\text { (epithelial) (CDH1) }\end{array}$ & NM_004360 & $\begin{array}{l}\text { (+) AAAGGCCCATTTCCTAAAAACCT } \\
\text { (-) TGCGTTCTCTATCCAGAGGCT }\end{array}$ & $\begin{array}{l}\text { PrimerBank } \\
\text { ID } 169790842 \mathrm{c} 3\end{array}$ \\
\hline Vimentin (VIM) & NM_003380 & $\begin{array}{l}\text { (+) AGTCCACTGAGTACCGGAGAC } \\
\text { (-) CATTTCACGCATCTGGCGTTC }\end{array}$ & $\begin{array}{l}\text { PrimerBank } \\
\text { ID } 240849334 \mathrm{c} 2\end{array}$ \\
\hline
\end{tabular}

*PrimerBank (Spandidos et al., 2010) [37]; PrimerBLAST (Ye et al., 2012) [38]

The search for new biomarkers for accurate prediction of UC outcome is a current challenge [5, 7]. In this context, our lab is focused on identification of new biomarkers for UC. Previously, we reported a positive correlation between the expression of Wnt5a and histopathological grade and stage of UC [6]. Our results suggest a potential value of $\mathrm{Wnt5}$ a signaling as a prognostic marker for UC.

In this study, we reported the expression of Wnt5a, Ror2 and an additional co-factor, CTHRC1, in the UC samples and urothelial cancer cell lines. The expression of CTHRC1 and the positive correlation between Wnt5a/Ror2 
and pathological grade suggests that the Wnt5a/PCP signaling pathway could play a role in the aggressiveness of this cancer.

Expression of Wnt5a has been reported in several types of cancers, but the role of Wnt5a in the pathogenic mechanisms of cancer is still unclear, with opposing roles as tumor promoter and tumor suppressor being described [22, 23]. Recently, Wnt5a/Ror2 signaling has been implicated as an important pathway in epithelialmesenchymal transition and promotion of invasion and metastasis in pancreatic cancer [24]. CTHRC1 is known as a regulator of collagen expression and cell migration $[23,25]$. The significance of CTHRC1 in the pathogenesis of cancer is still unclear, but its overexpression has been reported associated with poor prognosis in solid tumors, gastric and breast cancer [26-28]. Moreover, the inhibition of CTHRC1 using siRNA has been described as potential therapeutic strategy for cancer progression [12].

Interestingly, our results show a correlation between the expression of CTHRC1 and tumor grade in TUR samples, and the most aggressive of the three cell lines included in this study, J82, also expressed high transcription level of CTHRC1 gene. By immunofluorescence, presence of the Wnt5a protein in the three UC cell lines is clear. Even more interesting, confocal microscopy demonstrates the co-localization of Ror2 and CTHRC1, both receptors described in the non-canonical cell polarity pathway, most obvious in the $\mathrm{J} 82$ cell line. These results provide evidence for the potential activation of the Wnt5a/PCP pathway during UC pathogenesis. Taking into consideration all the above, our results suggest the potential role of Wnt5a/PCP pathway through the Ror2 signaling pathway in the development, progression and metastasis of bladder urothelial carcinoma.

Recently, expression of EMT-associated markers has been reported as potential predictors of recurrence in cases of non-muscle-invasive UC after TUR [29]. Specifically, E-cadherin has been reported as a potential prognostic marker for UC $[29,30]$. In line with these findings, our data shows that high grade UC cell line, J82 expressed high levels of Wnt5a and vimentin mRNA, but low levels of E-cadherin mRNA, suggesting a role of Wnt5a signaling in EMT in UC. Recently, Twist and Wnt signaling pathways have been associated with UC and metastatic breast cancer via activation of EMT genes transcription suggesting a potential therapeutic use by interference of these pathways [29, 31].

In conclusion, these data support our previous studies that suggest that the Wnt5a signaling pathway plays a pathological role in UC. A correlation between Wnt5a/Ror2 and pathological grade suggests that Wnt5a/Ror2 signaling pathway could play a role in the aggressiveness of this cancer, perhaps promoting the EMT and metastasis process. The results also support their potential use as molecular biomarkers and therapeutic target for UC. Further studies are needed to determine the underlying mechanism of Wnt5a/Ror2 action in the pathogenesis/progression of UC as well as their application as biomarkers for UC.

\section{MATERIALS AND METHODS}

\section{Epidemiologic study of human urothelial carcinoma}

Reports of patients with initial diagnosis of bladder tumor at the University Medical Associates Pathology Department (UMA Pathology lab, Athens, $\mathrm{OH}$ ) during a 10 year period (2004-2014) were reviewed. This study was performed after obtaining approval by the Ohio University Institutional Review Board (IRB 07E112). All cases were re-evaluated to confirm the initial diagnosis and each case was recorded and categorized by age, and sex. The diagnosis, determination of histological grade and pathological stage were verified on hematoxylin and eosin (H\&E) stained sections, based on the WHO/ISUP consensus classification system $[2,32]$. Histological grade was determined by evaluating tissue architecture, polarity, and cohesiveness, as well as cytological features such as pleomorphism, chromasia, and mitosis as described previously [2]. Pathological stage was determined by the depth of invasion into the lamina propria and muscularis propria. Descriptive statistics focused on frequencies and proportions for variables in this group $(n=77)$ was performed.

\section{Protein expression in UC samples by immunostaining}

Immunohistochemial staining of 15 formalin fixed paraffin embedded (FFPE), TUR samples, collected in 2013-2014, was performed. These 15 samples were included in the total of 77 cases reviewed for the epidemiologic study. The immunostaining was performed as previously described [6]. Briefly, for each case, two 4 $\mu \mathrm{m}$ sections were mounted onto a Superfrost glass slide. Sections were deparaffinized by xylene and rehydrated in decreasing concentrations of ethanol. After antigen retrieval using $10 \mathrm{mM}$ citrate buffer, $\mathrm{pH} 6.0$, at $90^{\circ} \mathrm{C}$ for 30 minutes, the endogenous peroxidase activity was blocked with $3 \% \mathrm{H}_{2} \mathrm{O}_{2}$ in phosphate buffered saline (PBS). To one of each of the two sections the following antihuman primary antibodies were applied: mouse monoclonal antibody against Wnt5a (Abcam, Cambridge, MA) applied at $8.33 \mu \mathrm{g} / \mathrm{ml}$; rabbit polyclonal antibody against Ror2 (Abnova, Taipei City, Taiwan) applied at $1 / 100$ dilution, and mouse monoclonal antibody against CTHRC1 (Abnova, Taipei City, Taiwan) applied at 4.0 $\mu \mathrm{g} / \mathrm{ml}$. All primary antibodies were diluted in $1 \%$ bovine serum albumin (BSA) in PBS and incubated overnight at $4^{\circ} \mathrm{C}$ in a humidified chamber. For each primary antibody the corresponding isotype control was applied at a 
similar concentration to the consecutive section on each slide; normal mouse IgG (Santa Cruz Biotechnology, Santa Cruz, CA) was applied as isotype control for Wnt5a and CTHRC1 and normal rabbit IgG (Santa Cruz Biotechnology, Santa Cruz, CA) as isotype control for Ror2.

The next day, after three washes with PBS, the slides were incubated with goat anti-mouse IgG (Abcam, Cambridge, MA) or goat anti-rabbit IgG (Abcam, Cambridge, MA) HRP labeled for 1 hour at room temperature. Following four washes with PBS, diaminobenzidine (DAB) chromogen (ThermoScientific, Waltham, MA) was applied for 3 minutes, and then the sections counterstained with hematoxylin, dehydrated and mounted with a coverslip.

The immunostaining for each antibody was scored in a semi-quantitative manner according to Allred et al. [33], briefly, based on intensity (intensity score) and extent (proportion score) of stained tumor cells viewed at 400x in 10 fields per section by two independent observers according to the following criteria: intensity; 0, weak or no staining, up to $3+$, most intensive staining; proportion: 0 , less than $25 \%$ of the tumor cells were stained; $1+, 25 \%$ to $50 \%$ of the tumor cells were stained; $2+$, moderate, $50 \%$ to $75 \%$ of the tumor cells were stained; $3+$, more than $75 \%$ of the tumor cells were stained. Cases with discrepant scores were re-evaluated jointly until agreement between observers was reached.

\section{In vitro studies}

In order to confirm our results on TUR samples collected from patients, we worked with three immortalized commercially available UC cell lines well known and characterized [34-36]: RT4 (ATCC ®HTB$\left.2^{\mathrm{TM}}\right)$, isolated form transitional cell papilloma and classified as differentiated low grade UC; J82 (ATCC HTB-1 ${ }^{\mathrm{TM}}$ ), derived from UC high histological grade that infiltrated into deep muscle (Stage T3); and T24 (ATCC HTB-4TM), derived from UC high histological grade (Table 1).

\section{Real-time RT-PCR analysis}

Total RNA was isolated from replicate cultures of J82, T24 and RT-4 cells grown to near confluency in six well plates $(\mathrm{N}=6$ for each) using TRIzol Reagent (Life Technologies Corporation, Carlsbad, CA). RNA samples were treated with DNase I to remove contaminating genomic DNA and repurified using the RNA Clean \& Concentrator-5 kit supplied with DNase I according to the manufacturer's instructions (Zymo Research Corp, Irvine, CA). Purified RNA was quantified using a Nanodrop 1000 spectrophotomenter (Thermo Scientific, Wilmington, DE). cDNA was synthesized from $1 \mu \mathrm{g}$ of RNA per $20 \mu \mathrm{l}$ cDNA reaction using the iScript cDNA Synthesis Kit (Bio-Rad, Hercules, CA). cDNA samples were assayed for relative target concentration via real-time RT PCR analysis using gene-specific primers (sequences in Table 2 were obtained from the PrimerBank database [37] or designed using the Primer-BLAST program [38]; primers were synthesized by integrated DNA Technologies, Inc., Coralville, IA) and the iTaq Universal SYBR Green Supermix with ROX and fluorescein reference dyes (Bio-Rad). Reactions were performed in duplicate amplifying $0.8 \mu \mathrm{l}$ of undiluted template cDNA in a total reaction volume of $20 \mu \mathrm{l}$ per sample using an annealing temperature of $55^{\circ} \mathrm{C}$. Cycle threshold $(\mathrm{Ct})$ values were converted to linear quantity values according to the delta $\mathrm{Ct}$ method [39]. Quantity values were then normalized for each sample and gene of interest by dividing each value by the geometric mean of the corresponding quantity values for the two most stable housekeeping genes, GAPDH and UBC out of five assessed (also HPRT1, SDHA, and B2M; Table 2 ) using a model-based variance estimation approach [39]. Normalized values for each gene of interest were finally compared between groups, relative to RT4.

\section{Immunofluoroscence}

Three urothelial carcinoma cell lines HTB-4TM (T24), HTB-1 ${ }^{\mathrm{TM}}$ (J82) and HTB-2TM (RT4) (ATCC, Manassas, VA), were cultured according to ATCC recommendations or as described previously by Malgor et al. [6]. The cells were grown in chamber slides for 24 hours and after two washes with cold PBS, the cells were fixed in $4 \%$ buffered formalin for 10 minutes. Cells were incubated with the same primary antibodies described above for Wnt5a, Ror-2 and CTHRC-1 for one hour at room temperature. The secondary antibody used for Wnt5a and CTHRC1 was goat polyclonal anti mouse IgG Alexa Flour 568 and for Ror2 was goat polyclonal anti rabbit IgG Alexa Flour 488, incubated for 30 minutes. Slides were washed, stained with DAPI and visualized on a Nikon Eclipse A1 Ti-E confocal microscope. For better visualization of $\mathrm{Wnt5}$ a expression in the three cell lines, the 568 emission spectra was changed to 488 using the NIS Elements Ar Imaging software (Nikon).

\section{Statistical analyses}

Logistic regression statistical analysis was performed to investigate the correlation between Wnt5a immunostaining and Ror2 immunostaining, CTHRC1 immunostaining, tumor histological grade, and pathological stage. Statistical significance was tested at an alpha of 0.05. The software PASW Statistics 18 was used for data analysis (Pearson Education, New York City, NY). Real-time RT PCR results are expressed as mean \pm SEM. They were analyzed statistically using one-way analysis of variance (ANOVA) comparing RT4, J82 and T24 normalized expression values followed by Tukey post-hoc analyses. Results were considered statistically significant at $P<0.05$. 


\section{Author contributions}

Mark Saling and Jordan K. Duckett contributed equally to this work, they designed the experiments, performed the experiments, analyzed and interpreted data, and wrote and edited the manuscript.

IA designed the experiments, performed the experiments, analyzed and interpreted IF/confocal data and wrote and edited the manuscript.

$\mathrm{KC}$ designed the experiments, performed the experiments, analyzed and interpreted data and wrote and edited the manuscript.

SJ provided human cases, analyzed and interpreted data, and wrote and edited the manuscript.

RM designed the experiments, performed the experiments, analyzed and interpreted data and wrote and edited the manuscript.

\section{ACKNOWLEDGMENTS}

This study was supported in part by the Office of Research and Grants, Heritage College of Osteopathic Medicine, Ohio University.

We thank Dr. Monica Burdick for providing some reagents used in the study.

\section{CONFLICTS OF INTERESTS} this study.

There is no financial conflict of interest concerning

\section{REFERENCES}

1. Inc. ACS. Cancer Facts \& Figures 2014. 2014.

2. Epstein JI, Amin MB, Reuter VR, Mostofi FK. The World Health Organization/International Society of Urological Pathology consensus classification of urothelial (transitional cell) neoplasms of the urinary bladder. Bladder Consensus Conference Committee. Am J Surg Pathol. 1998; 22: 1435-48.

3. Cheung G, Sahai A, Billia M, Dasgupta P, Khan MS. Recent advances in the diagnosis and treatment of bladder cancer. BMC Med. 2013; 11: 13. doi: 10.1186/1741-7015-11-13.

4. Pan CC, Chang $\mathrm{YH}$, Chen KK, Yu HJ, Sun $\mathrm{CH}$, Ho DM. Prognostic significance of the 2004 WHO/ISUP classification for prediction of recurrence, progression, and cancer-specific mortality of non-muscle-invasive urothelial tumors of the urinary bladder: a clinicopathologic study of 1,515 cases. Am J Clin Pathol. 2010; 133: 788-95. doi: 10.1309/AJCP12MRVVHTCKEJ.

5. Coleman JF, Hansel DE. Utility of diagnostic and prognostic markers in urothelial carcinoma of the bladder. Adv Anat Pathol. 2009; 16: 67-78.

6. Malgor R, Crouser S, Greco D, Brockett C, Coschigano K, Nakazawa M, Jenkinson S. Correlation of Wnt5a expression with histopathological grade/stage in urothelial carcinoma of the bladder. Diagn Pathol. 2013; 8: 139. doi: 10.1186/1746-1596-8-139.

7. Chen YB, Tu JJ, Kao J, Zhou XK, Chen YT. Survivin as a useful adjunct marker for the grading of papillary urothelial carcinoma. Arch Pathol Lab Med. 2008; 132: 224-31.

8. Gordon MD, Nusse R. Wnt signaling: multiple pathways, multiple receptors, and multiple transcription factors. J Biol Chem. 2006; 281: 22429-33.

9. Habas R, Dawid IB. Dishevelled and Wnt signaling: is the nucleus the final frontier? J Biol. 2005; 4: 2. doi: 10.1186/ jbiol22.

10. Kumawat K, Gosens R. WNT-5A: signaling and functions in health and disease. Cell Mol Life Sci. 2016; 73: 567-87. doi: 10.1007/s00018-015-2076-y.

11. Shao Y, Zheng Q, Wang W, Xin N, Song X, Zhao C. Biological functions of macrophage-derived Wnt5a, and its roles in human diseases. Oncotarget. 2016; 7: 67674-84. doi: 10.18632/oncotarget.11874.

12. Camilli TC, Weeraratna AT. Striking the target in Wnt-y conditions: intervening in Wnt signaling during cancer progression. Biochem Pharmacol. 2010; 80: 702-11. doi: 10.1016/j.bcp.2010.03.002.

13. Asem MS, Buechler S, Wates RB, Miller DL, Stack MS. Wnt5a Signaling in Cancer. Cancers (Basel). 2016; 8. doi: 10.3390/cancers8090079.

14. Kohn AD, Moon RT. Wnt and calcium signaling: betacatenin-independent pathways. Cell Calcium. 2005; 38: 439-46. doi: 10.1016/j.ceca.2005.06.022.

15. Green J, Nusse R, van Amerongen R. The role of Ryk and Ror receptor tyrosine kinases in Wnt signal transduction. Cold Spring Harb Perspect Biol. 2014; 6. doi: 10.1101/ cshperspect.a009175.

16. Yamamoto S, Nishimura O, Misaki K, Nishita M, Minami Y, Yonemura S, Tarui H, Sasaki H. Cthrc1 selectively activates the planar cell polarity pathway of Wnt signaling by stabilizing the Wnt-receptor complex. Dev Cell. 2008; 15: 23-36. doi: 10.1016/j.devcel.2008.05.007.

17. Ren D, Minami Y, Nishita M. Critical role of Wnt5aRor2 signaling in motility and invasiveness of carcinoma cells following Snail-mediated epithelial-mesenchymal transition. Genes Cells. 2011; 16: 304-15. doi: 10.1111/j.1365-2443.2011.01487.x.

18. Dissanayake SK, Wade MS, Johnson CE, O'Connell M P, Leotlela PD, French AD, Shah KV, Hewitt KJ, Rosenthal DT, Indig FE, Jiang Y, Nickoloff BJ, Taub DD, et al. The WNT5A/PKC pathway mediates motility in melanoma cells via the inhibition of metastasis suppressors, and initiation of an epithelial to mesenchymal transition. J Biol Chem. 2007.

19. Ma MZ, Zhuang C, Yang XM, Zhang ZZ, Ma H, Zhang WM, You H, Qin W, Gu J, Yang S, Cao H, Zhang ZG. CTHRC1 acts as a prognostic factor and promotes invasiveness of gastrointestinal stromal tumors by activating Wnt/PCP-Rho signaling. Neoplasia. 2014; 16: 265-78, 78 e1-13. doi: 10.1016/j.neo.2014.03.001. 
20. Division ACSEC. Ohio Department of Health, The Ohio State University. Ohio Cancer Facts \& Figures 2010. 2010.

21. Babjuk M, Burger M, Zigeuner R, Shariat SF, van Rhijn BW, Comperat E, Sylvester RJ, Kaasinen E, Bohle A, Palou Redorta J, Roupret M. European Association of U. EAU guidelines on non-muscle-invasive urothelial carcinoma of the bladder: update 2013. Eur Urol. 2013; 64: 639-53. doi: 10.1016/j.eururo.2013.06.003.

22. McDonald SL, Silver A. The opposing roles of Wnt-5a in cancer. Br J Cancer. 2009; 101: 209-14.

23. Nishita M, Enomoto M, Yamagata K, Minami Y. Cell/ tissue-tropic functions of Wnt5a signaling in normal and cancer cells. Trends Cell Biol. 2010; 20: 346-54. doi: 10.1016/j.tcb.2010.03.001.

24. Bo H, Zhang S, Gao L, Chen Y, Zhang J, Chang X, Zhu M. Upregulation of Wnt5a promotes epithelial-to-mesenchymal transition and metastasis of pancreatic cancer cells. BMC Cancer. 2013; 13: 496. doi: 10.1186/1471-2407-13-496.

25. Pyagay P, Heroult M, Wang Q, Lehnert W, Belden J, Liaw L, Friesel RE, Lindner V. Collagen triple helix repeat containing 1 , a novel secreted protein in injured and diseased arteries, inhibits collagen expression and promotes cell migration. Circ Res. 2005; 96: 261-8. doi: 10.1161/01. RES.0000154262.07264.12.

26. Tang L, Dai DL, Su M, Martinka M, Li G, Zhou Y. Aberrant expression of collagen triple helix repeat containing 1 in human solid cancers. Clin Cancer Res. 2006; 12: 3716-22. doi: 10.1158/1078-0432.CCR-06-0030.

27. Wang P, Wang YC, Chen XY, Shen ZY, Cao H, Zhang YJ, Yu J, Zhu JD, Lu YY, Fang JY. CTHRC1 is upregulated by promoter demethylation and transforming growth factor-beta1 and may be associated with metastasis in human gastric cancer. Cancer Sci. 2012; 103: 1327-33. doi: 10.1111/j.1349-7006.2012.02292.x.

28. Kim JH, Baek TH, Yim HS, Kim KH, Jeong SH, Kang HB, Oh SS, Lee HG, Kim JW, Kim KD. Collagen triple helix repeat containing-1 (CTHRC1) expression in invasive ductal carcinoma of the breast: the impact on prognosis and correlation to clinicopathologic features. Pathol Oncol Res. 2013; 19: 731-7. doi: 10.1007/s12253-013-9636-y.

29. Liu B, Miyake H, Nishikawa M, Fujisawa M. Expression profile of epithelial-mesenchymal transition markers in non-muscle-invasive urothelial carcinoma of the bladder: correlation with intravesical recurrence following transurethral resection. Urol Oncol. 2015; 33: 110 e11-8. doi: 10.1016/j.urolonc.2014.08.012.

30. Khorrami MH, Hadi M, Gharaati MR, Izadpanahi MH, Javid A, Zargham M. E-cadherin expression as a prognostic factor in transitional cell carcinoma of the bladder after transurethral resection. Urol J. 2012; 9: 581-5.

31. Glackin CA. Targeting the Twist and Wnt signaling pathways in metastatic breast cancer. Maturitas. 2014; 79: 48-51. doi: 10.1016/j.maturitas.2014.06.015.

32. Eble JN, Sauter G, Epstein JI, Sesterhenn IA. World Health Organization Classification of Tumours: Pathology and Genetics of Tumrous of the Urinary System and Male Genital Organs. Lyon, France: IARC Press. 2004.

33. Allred DC, Harvey JM, Berardo M, Clark GM. Prognostic and predictive factors in breast cancer by immunohistochemical analysis. Mod Pathol. 1998; 11: 155-68.

34. Masters JR, Hepburn PJ. Human bladder cancer in vitro drug sensitivities: range and stability in long-term culture. Br J Cancer. 1986; 54: 131-5.

35. O'Toole C, Price ZH, Ohnuki Y, Unsgaard B. Ultrastructure, karyology and immunology of a cell line originated from a human transitional-cell carcinoma. Br J Cancer. 1978; 38: 64-76.

36. Masters JR, Hepburn PJ, Walker L, Highman WJ, Trejdosiewicz LK, Povey S, Parkar M, Hill BT, Riddle PR, Franks LM. Tissue culture model of transitional cell carcinoma: characterization of twenty-two human urothelial cell lines. Cancer Res. 1986; 46: 3630-6.

37. Spandidos A, Wang X, Wang H, Seed B. PrimerBank: a resource of human and mouse PCR primer pairs for gene expression detection and quantification. Nucleic Acids Res. 2010; 38: D792-9. doi: 10.1093/nar/gkp1005.

38. Ye J, Coulouris G, Zaretskaya I, Cutcutache I, Rozen S, Madden TL. Primer-BLAST: a tool to design target-specific primers for polymerase chain reaction. BMC Bioinformatics. 2012; 13: 134. doi: 10.1186/1471-2105-13-134.

39. Andersen CL, Jensen JL, Orntoft TF. Normalization of realtime quantitative reverse transcription-PCR data: a modelbased variance estimation approach to identify genes suited for normalization, applied to bladder and colon cancer data sets. Cancer Res. 2004; 64: 5245-50. 